\title{
Sorani Kurdish Address Forms: Case of Northwest Iran
}

\author{
Hiwa Asadpour \\ Dept. of Linguistics, Science and Research branch \\ Islamic Azad University, Tehran, Iran \\ Tel: 98-936-405-8458Ｅ-mail: hiva2005e@yahoo.com \\ Jahanbakhsh Louragi-pour \\ Islamic Azad University, Kahnouj branch, Iran \\ E-mail: igarool@yahoo.com \\ Mehdi Safaie Qalati (Corresponding author) \\ Dept. of Linguistics, Tarbiat Modares University, Tehran, Iran \\ Tel: 98-935-865-1011_E-mail: amensad@gmail.com
}

Received: August 16, 2012 Accepted: September 10, 2012 Published: December 31, 2012

doi:10.5296/ijl.v4i4.2252

URL: http://dx.doi.org/10.5296/ijl.v4i4.2252

\begin{abstract}
Our study aims at ascertaining and formulating a framework that would account for the Kurdish data. We scrutinize all the dyads that occur in the selected corpus, and describe how they usually work on the basis of the two following variables: power and intimacy. According to our investigation, the use of terms of address in Kurdish is affected by the age, sex, occupation, ideology, political and social position of the interlocutors which can be stated as a result of the investigation of older material - such as qualitative analysis of observation followed by unobtrusive note taking of contemporary use, a corpus of several plays, accounts of travel, interviews, TV, radio and the careful observation of the use of terms of address of today. Kurdish culture is title + first-name and title + family name oriented. Titles like 'doctor,' 'professor,' and 'teacher' are used, with title and family names. First names in Kurdish culture are restricted in use. They are used most commonly among peer groups of young generation, and by an older person addressing a child or a younger person in the family.
\end{abstract}




\section{Macrothink}

International Journal of Linguistics

ISSN 1948-5425

2012, Vol. 4, No. 4

Cognitively, Kurdish tends toward a holistic style and it puts the group, family, and country before the individual.

Keywords: Address terms, Critical discourse analysis, Politeness, Power semantics, Solidarity semantics, Kurdish 


\section{Introduction}

Halliday distinguished three main functions for language: ideational, textual and interpersonal. The interpersonal function is to indicate and establish social relationships between people in a society; it includes terms of address, speech functions, etc. (Halliday, 1978). Fasold (1990) believes that in no area of sociolinguistics this function of language is more highlighted than in address forms.

The study of address terms investigates social attitudes, social structures and group ideology (Lee-Wong, 1994). In addition, cultural norms and values are reflected in the address system. For example, if in a language a number of variants in the address system refer to religious terms like 'mollâ' and 'Seix' (Arabic loan words in Persian, Kurdish, and other Iranian Languages denoting 'clergyman'), this shows the important status of religion in the respective culture (Braun, 1988).

\section{Review of the Literature}

Researchers in the field of sociolinguistics have long been interested in investigating both the process by which people are socialized into cultural practices and the meanings that are associated with such practices (Sandel, 2002). The study of address terms is associated with the names of Brown \& Ford: Address in American English (1961), Brown \& Gilman: The Pronouns of Power and Solidarity (1960), Brown \& Gilman: The Pronouns of Solidarity and Power (1972), and Brown \& Levinson: Universals in Language Useage: Politeness Phenomena (1978). These scholars found two forces triggering the use of address terms: power and solidarity. Some instances exhibit the FN vs. TLN distribution or the T/V distinction in older AE, that is, "thou" and "you" respectively, but in standard contemporary English, there is only one pronoun of address, namely "you".

Bates and Benigni (1975) examined the pronouns of address in Italy as a function of sociological parameters of age, sex and social class. They used a modified version of the Brown and Gilman's questionnaire in interviewing 117 Italian adults. Their results indicate a powerful age-class interaction in overall degrees of formality. They found out that there are three pronouns of address in the Italian address system: 'tu' $(\mathrm{T})$, 'voi' $\left(\mathrm{V}_{1}\right)$ and 'lei' $\left(\mathrm{V}_{2}\right)$. So it has a threefold distinction which is not considered by Brown and Gilman (Bates \& Benigni, 1975, p. 271). According to them young upper class $S_{s}$ are the least formal of the social groups; LC youths are the most formal, while older Ss fall in between. Regarding the relationship between politics and address forms, Bates and Benigni (1975, p. 280) found that: "+conservatism $=+$ formality". It means that those who are conservative use formal variants while addressing others. Sex differences are not as important as age, political, and social class in the selection of address variants in Italy. From these factors, age differences are the major status differences likely to trigger non-reciprocal address.

Paulston believed that a linguistic description is not possible without considering social and historical aspects of the society, so she highlighted that one can describe the Swedish address system adequately only if one recognizes that the social classes have different rules of use due to different 'semantics' for the pronoun $\boldsymbol{d u}$ and $\boldsymbol{n i}$ (Paulston, 1976, p. 364). According to 
Paulston (1976, p. 364), old Swedish had only one singular pronoun of address, 'du', used for friends and strangers alike. In the 1600s, under the influence of usage at Byzantine court, the plural pronoun 'I' came to be used to address a single person. This pronoun 'I' developed into 'ni' from the plural suffix ' $n$ ' of the preceding verb as in 'haven I' "do you have?". During the 1700s, under the influence of French, the Swedish elite developed the ' $\mathrm{du} / \mathrm{ni}$ ' dichotomy from 'tu' and 'vous' in French. There are two distinct meanings of 'du' with two different semantics: intimacy-familiarity and solidarity. When 'du' co-occurs with FN or KT, it signals intimacy-familiarity. For example, when a person addresses his brother with 'du-broder' ["du-brother"], it shows intimacy. But intimacy is not signaled by FN alone, a combination of du+FN is used to imply intimacy (Paulston, 1976, p. 370). On the other hand, 'du' by itself expresses solidarity, but not intimacy. University students address their professors with 'du' as an expression of group membership.

Mcgivney found that rules for address in Mijikenda are based on kinship but are extended to affines. According to this study, kin or affines of the same generation and also of alternate generations always use reciprocal singular forms, so pronoun selection is unaffected with regard to relative or absolute age. He also understood that address systems underlie the social norms of respect and dependency between children and their parent's generations and alternative values of non-respectful joking relationships between them (Mcgivney, 1993, p. 13).

Lee-Wong (1994, pp. 302-3) studied the relationship between shifting semantics and the changing ideology in the address system of Chinese. Chinese's system of address is rooted in a social structure that attaches great significance to kinship. Lee-Wong (1994, pp. 302-3) arrived at interesting results as follows: (a) age has precedence over group consciousness (b) in formal situations status is more significant than age and (c) in informal settings age plays a more important role than status. He examined address forms and their semantic shifts in three sociopolitical periods: (1) pre and post-1949 Revolution, (2) the Cultural Revolution, and (3) the post-Cultural Revolution. For example, he examined the development and semantic shift of address form 'tangzhi'; it meant "follower" when it was first developed by Dr. Sun Yat Sen. Before and during the 1949 revolution it had connotations of equality, respect, intimacy and revolutionary solidarity. During the Cultural Revolution it lost its strong connotations of respect and intimacy and after the Cultural Revolution it became a marker of formality and distance (Lee-Wong, 1994, pp. 305-6).

Oyetade (1995, p. 519) provided a descriptive analysis of the entire system of address forms in Yoruba, a Defoid language of the Niger-Congo tribe spoken in the western part of Nigeria and also in the Republics of Benin and Togo. Oyetade (1995) found that address terms in Yoruba are pronouns, names, KTs, titles and occupational terms. Among these variants, names are the most common forms of address and among names the reciprocal use of PN is the rule between friends, close relatives and members of the same age group.

Saberi (2002, p. 23) studied the understanding level of non-Farsi speakers of the social functions of Persian address terms as a second language. He administered a self-made questionnaire to 30 Tehrani senior university students studying at Razi University, 
Kermanshah, Iran, and 30 foreign students studying Persian as a second language at Qazvin International University, Qazvin, Iran. The foreign students were all Arabs and from countries such as Iraq, Lebanon, Palestine, Syria and Sudan. Using a t-test, he discovered that non-Farsi speakers have a low understanding of the social functions of Persian address terms. He also found that Persian has a complicated address system that include pronouns, names, titles, KTs, endearment terms, reproof terms and zero forms. Saberi's (2002) case demonstrates that in learning any foreign language the social behavior of the target culture is more important than just learning the vocabulary and grammar of that language.

\section{Power, Ideology and Terms of Address}

For Hodge and Kress (1996, p. 6) "language is an instrument of control as well as a means of communication". Every linguistic unit may be used to exercise power in some way or communicate knowledge, skills, and beliefs. Here, we are concerned with the relationship between power, ideology and terms of address.

Fairclaugh (1989, p. 29) regards discourse as discoursal action, actual talk or writing. He uses the term language in a parallel way to refer to discourse action or to specific instances of talking or writing. Van Leeuwen (1993, p. 193) believes that there are two kinds of relations between discourse and social practice. The first is that discourse itself is social practice. It is a form of action and something people do to, for, or with each other. The second is that discourse is a way of presenting social practice. It is a form of knowledge and the things people say about social practice. Since the study of discourse is the study of any aspect of language use (Fasold, 1990, p. 68) and address terms are specific instances of language use and the aim of CDA is to critically investigate social inequality as it is expressed and constituted by language use (or in discourse) (Wodak \& Meyer, 2001, p. 2), we must find assumptions that legitimize power relations between people. According to (Fairclaugh, 1989, pp. 3-4) power is exercised in two ways: through coercion of various kinds including physical violence, and through the manufacturing of consent. Ideologies are the prime means of manufacturing consent. In modern societies, people rarely exercise power through physical coercion, but use language to achieve this end.

When people use language, or behave in a specific manner or interact with each other, they convey implicit conventions or commonsense assumptions of which they are not generally aware. These assumptions are ideologies and are closely associated with power, because these assumptions and conventions that make them are dependent on power relations in society. According to Fairclaugh (1989, pp. 1-2) these conventions have a dual relation to power, "on the one hand, they incorporate differences in power, and on the other hand they arise out of -and give rise to- particular relations of power".

Power relations are inherently asymmetrical because two people cannot exert power over each other in the same direction or in the same area of behavior. This non-reciprocal power relation only exists between a superior and an inferior, so it calls for a social structure in which every individual has a specific right by his/her conditions of birth, and power relations are so rigid that there is almost no mobility. In such a society, if a person was born in a powerful family, he was superior for the whole of his life and if he was born in a powerless 
family, he remained inferior for his life and no changes occurred in power positions. Most of the differences in power relation are differences and inequality in economic and political relations, thus, power is largely linked to class or caste positions. Violating power relations implies that a speaker thinks of the other as his inferior, superior or equal.

Ideological assumptions are not used only for sustaining unequal power relations. They are also used for establishing and maintaining solidarity relations between members of a community (Fairclaugh, 1989, p. 84). Solidarity relations are necessarily reciprocal since they imply a sharing between people and a degree of intimacy. The attributes for asserting solidarity are different. According to Foley (1997, p. 315) the most important of them are: "political party membership, family background, religious affiliation, gender or sexual orientation, roughly equal age, etc." Violating solidarity relations means that a speaker considers the other as an outsider or an intimate to him/ her.

In ancient Latin there was only 'tu' to address one person, and 'vous' was used to address more than one person. The use of 'vous' to one person was first directed to the emperor. By that time there were only two emperors in the world: the ruler of the eastern empire sat in Constantinople and the ruler of the west who had his seat in Rome. The reverential 'vous' was inspired by the power of the emperor and then was extended to other power figures. Until about 200 years ago, the European social structure was feudal and approximately a caste society. The nobility said ' $\mathrm{T}$ ' to the common people and received ' $\mathrm{V}$ '. With the Industrial Revolution, a social structure began to emerge based on one's economic position and mobility of power occurred widely in society, so the power semantics was not sufficient to underlie the address behavior in speech communities. According to Fasold (1990, p. 4) not all differences between people are differences in power relations. Two people can be equally powerful in the social order, but be from different families or have different professions, so the development of solidary semantics was necessary. If equally powerful people were solidary, they would exchange ' $\mathrm{T}$ ' and if they were not solidary, they would address each other by the "V" form. Brown and Gilman (1972) illustrate this as in figure 3.1.

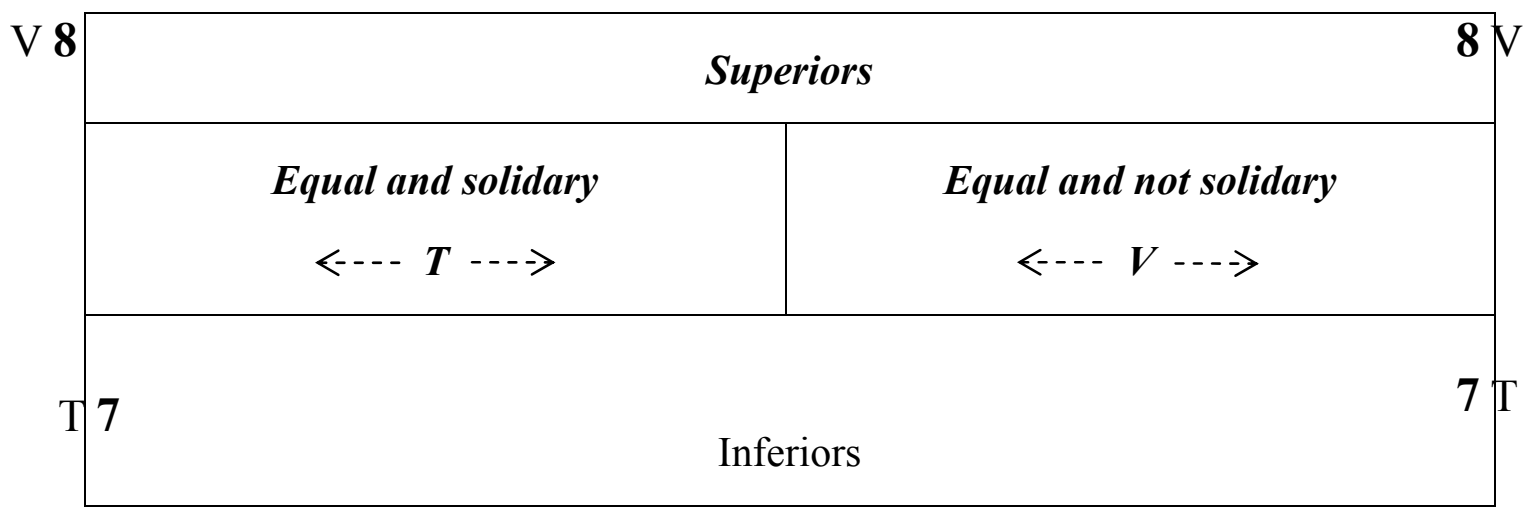

Figure 3.1. The two dimensional semantic in equilibrium Source: Brown \& Gilman (1972, p. 259). Figure 1a 
In this figure and the following one, the direction of arrows upwards shows that inferiors address superiors with $\mathrm{V}$ form and downwards indicates that superiors address inferiors with $\mathrm{T}$ form. Bi-directional arrows show reciprocity. It means that those who are equal and solidary use mutual $\mathrm{T}$ and those who are equal, but not solidary, address each other by the ' $\mathrm{V}$ ' form.

In SK, the T/V exists and it is shown by names and titles too. $\mathrm{FN}$ is roughly equivalent to the $\mathrm{T}$ form and $\mathrm{T}+\mathrm{LN}$ is similar to the ' $\mathrm{V}$ ' form. As we will see in 7.4., in a conversation at the Post Office, the manager addresses the fellow clerk with FN because he has power over him and receives TLN in return, since the fellow clerk sees himself in an inferior position. Two close friends who are equal and solidary, use appellations to address each other.

Fasold (1990) also states that in some cases some conflicts may occur between power and solidarity. For example, in a restaurant a patron has power over a waiter and power semantics entitles the customer to address the waiter with ' $\mathrm{T}$ ', but because they are strangers; and so not solidary, the solidarity semantics dictates ' $\mathrm{V}$ '. This is also seen between employers and employees. Having power over the employee, the employer can address him with the $T$ form. In these cases, because there is low solidarity, mutual ' $\mathrm{V}$ ' is exchanged. Parents and children are solidary, so solidarity semantics calls for mutual ' $\mathrm{T}$ ', but the power semantics would lead a child to address his/her parent with ' $\mathrm{V}$ '.

When solidarity takes on greater importance, conflicts of this type arise. Brown \& Gilman (1972) summarize the modern usage as in figure 3.2.

\begin{tabular}{|c|c|c|c|c|}
\hline $\mathrm{V} \varnothing$ & Superior and solidary & $\mathrm{T}$ & $\mathrm{V}$ & Superior and not solidary \\
\hline & $\begin{array}{l}\text { Equal and solidary } \\
\ldots \ldots . . \cdots\end{array}$ & & & 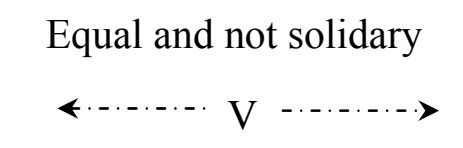 \\
\hline $\mathrm{T} 7$ & Inferior and solidary & $\mathrm{V}$ & $\mathrm{T}$ & Inferior and not solidary \\
\hline
\end{tabular}

Figure 3.2. The two - dimensional semantic under tension

Source: Brown \& Gilman (1972, p. 259) Figure-1b

In this chart, the problematic cases are the upper left and lower right hand boxes in which power and solidarity semantics conflict. The other boxes are like figure 3.1, in which mutual ' $\mathrm{T}$ ' or ' $\mathrm{V}$ ' or the non-reciprocal uses of ' $\mathrm{V}$ ' are used. In the problematic boxes, superior in power calls for ' $\mathrm{V}$ ' but solidarity suggests ' $\mathrm{T}$ ', and inferior in power is indicated by ' $\mathrm{T}$ ', while not solidary is marked by ' $\mathrm{V}$ '. In these cases, as mentioned before, in modern Europe by the mid-twentieth century, the solidarity semantics won over power, requiring mutual ' $\mathrm{T}$ ' in the first instance and mutual ' $\mathrm{V}$ ' in the second.

In brief, there is a strong relationship between power, ideology and terms of address because 
address behavior is based on implicit conventions and assumptions that arise from power relations among people. These assumptions are ideologies and ideological assumptions are used not only for sustaining power relations but also for maintaining solidarity relations between speakers in a speech community.

\section{Research Questions}

Our main questions are: What is the relation between power, ideology and the terms of address? How do power and ideology affect the use of address terms? How do the development and the shift from power semantics to solidarity take place? Why is a particular address term used in a specific situation and to whom? How are the criteria like age, sex, education, social and occupational status of interlocutors in a dyad reflected in terms of address in SK? In other words, what is the relation between terms of address and social structure in SK?

\section{Significance of the Study}

In this study, the main interest would be on contemporary usage; after the Islamic Revolution in Iran and the 1991 uprising in Iraq, some changes have occurred in SK address system which are of great importance and are included as innovations in SK. It is important to discuss the development of power semantics and its shift to solidarity; the present study is supposed to consider this through the aforementioned approaches by presenting data that show how this cultural practice is evoked in the Iranian society, and these meanings are linked to this practice by the interlocutors.

An inappropriate choice of the address terms hinders communication between the speaker and the addressee. This becomes particularly crucial in cross-cultural contexts. Without understanding the social norms and cultural aspects of the target language, foreign language learners or second language learners may fail to use the proper address terms in a particular speech context, or they may not properly transfer the usage of address terms from native to target language; this also could enhance the importance of conducting studies such as the present one on SK.

\section{Data Collection}

We applied a qualitative methodology for the present study. Through our field research, we had "observation of participants" (experiencing), "interviews" (enquiring) and "study materials prepared by others" (examining) (Bryman, 1984, and Wolcott, 1994, p. 10).

For terms of address used in the past, we drew on plays, accounts of travel, encyclopedias and letters related to that period. We also informally interviewed 10 people regarding the use of address terms in the past. For contemporary usage, we observed people in different situations ranging from informal (e.g. at home) to formal (e.g. at the office). This was supported by material collected (personally) whenever interlocutors were using address terms in a given situation e.g. a conversation between a manager of the post office and one of the clerks, or a conversation during a family gathering, which is/was illuminating for the use of KTs. We also made use of short radio and TV programs from Mahabad (a local Iranian TV) 
and Kurdistan TV. The motivation for using them was to collect reliable data in natural situations from other parts of Iran, Iraq etc. where SK is spoken.

Among the films and TV series, zārā is based on a true story happened around 1320 in Mahabad. This movie was chosen because there are a lot of address forms in it and the terms used are related to a specific period of time in one part of Kurdistan. " yāni tât" ("a terrible life") is about the life conditions of Kurdish people working in brick-kilns and cow-sheds. The choice of this film was motivated by the consideration that it contained some borrowed terms of address in SK. The other programs were as follows: Gcerān boedwāi sēboercekāndā ("searching for shades"), a TV series consisting of 10 forty-five minute episodes shown on Kurdsat TV, beernāmcei bcernāmce ("the program of program"), a scoffing program shown every week on Kurdsat TV. The aim of examining these programs was to investigate terms of address in Iraq where a large number of the SK speakers live.

The data collected over this period were supplemented by our introspection as a native speaker of the SK. We also interviewed 10 people informally regarding the use of address terms in the past. For contemporary usage, we observed people in different situations ranging from informal (e.g. home) to formal (e.g. office). This was followed by unobtrusive note taking at every opportunity to record terms used by interlocutors in a given situation. For instance, we observed a conversational exchange between the post office manager and one of the fellow clerks in post office. In these situations, we were passive participants, but in other situations we were active participant and interacted with other speakers in the use of address terms. We also participated in a family gathering in which KTs were used. The observation was conducted over a period of twelve months.

\section{Terms of Address in Kurdish}

\subsection{Kinship Terms}

According to Braun (1988, p. 9) "KTs are terms for blood relations and for affines". Foley (1997) believes that KTs should be studied from two perspectives: universalist and relativist. Kinship systems are good domains to show the universals, because marrying and reproduction is a necessary feature of any society. Foley (1997) sees the nuclear family as the universal feature of all languages from which wider kinship systems are derived through a process of extension.

The relativistic view is that kinship terminologies are not structured in biological and genealogical terms but in social ones. It means that individuals are not classified into particular kin categories by biological relationships, but by their membership in particular social groupings, especially descent and marriage connections.

In SK, KTs are probably the most widely used forms of address, for they constitute an integral part of the address system and reference in the language. These forms, according to their part of speech, are nouns that reflect blood relations among family members (mother, father, brother, sister, etc.) as well as in-laws. Among nonfamily members and even strangers, they can also be used as social honorifics that reflect varying degrees of politeness and 


\section{Al Macrothink}

International Journal of Linguistics

ISSN 1948-5425

2012, Vol. 4, No. 4

respect. Thus, they create an atmosphere of solidarity and enhance interaction among participants in conversations. This particular use of a kinship form in addressing a non-relative is often called "a fictive" (Braun, 1988). The choice of KTs available to the users vary depends on the context in which they are non-family members and even strangers, they can also be used as social honorifics that reflect varying degrees of politeness and respect.

\section{A greeting in a meeting:}

The young man:

\section{"scelām māmce"}

"Hello, uncle"

The old man: "thi? tfot gut?"

"What? What did you say?"

The young man: “maenzurēkam naebu”

"I did not mean anything."

The old man in this conversation had a young girl. The KT mämce ("uncle") is used in two occasions: either to address one's father's brother or to refer to one's wife's father. In the Kurdish culture, the use of mämoe is considered impolite except in these two occasions, especially if the addressee has a young girl because it is thought that the boy loves the girl. As we saw in this conversation, the use of an inappropriate address term can lead to a misunderstanding.

Table 7.1. KTs in SK

\begin{tabular}{|l|l|}
\hline Sorani KT & English Equivalent \\
\hline bābæ, bāwk & father \\
\hline dāyæ, diya, dāyk & mother \\
\hline kāk, kākæ & elder brother \\
\hline brā & brother \\
\hline bāji & elder sister \\
\hline xō $k$ k & sister \\
\hline mām, māmæ & uncle (father's brother) \\
\hline xāłæ, xāł ,xāłō & uncle ( mother's brother) \\
\hline
\end{tabular}




\begin{tabular}{|c|c|}
\hline bāpir, bāpiræ, bābæ gæwræ & grandfather \\
\hline nænæ, nænke, dāyæ gæwræ & grandmother \\
\hline Pāmō3ən - māmō3ən & uncle's wife \\
\hline xāłō3ən & uncle's wife \\
\hline brā3ən & brother's wife \\
\hline pur, pure & Aunt \\
\hline Pāmōzā & cousin \\
\hline xāłōzā & cousin \\
\hline purzā & cousin \\
\hline xwārzāa xō $\int k æ z \bar{a}$ & nephew, niece \\
\hline brāzā & nephew, niece \\
\hline bābi bābəm & my father's father \\
\hline dāyki dāykəm & my mother's mother \\
\hline piyāwækæ & (my) husband \\
\hline Pāfræt & (my)wife \\
\hline rōłæ & (my) child \\
\hline kurækæm & my son \\
\hline kət $\int æ k æ m$ & my daughter \\
\hline
\end{tabular}

Some of these terms like $b r \bar{a} z \bar{a}$, purza and $x \bar{a} t \bar{o} z \bar{a}$ are used alone. Terms like $k \bar{a} k, m \bar{a} m, x \bar{a} t$ can be used alone or with FN. Others like bäbce, dāyce are used alone or along with titles, for

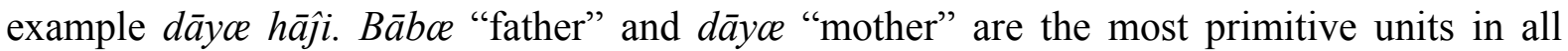
kinship systems and they are the most widely used in SK.

Regarding the structure of the family in the past, the interviewees told me the structure of the most families used to be extended such that people lived with their parents, aunts, uncles, 
cousins, nephews, ... . So the use of terms like $x \bar{a} t \bar{o} z \bar{a}$, purzāa, 7āmōzz $\bar{a}$ had been common during those days. Today this structure is only found in villages and, along with the change of extended families to nuclear ones, the use of these terms has gradually disappeared; instead, other variants like personal names or titles are now used. In our observations, we never encountered the use of these terms between speakers in a dyad.

SK KTs can be used beyond their primary use so that when we don't have a definite relationship with a person, according to their age, sex, generation, etc. we can choose a kind of KT to refer to them. This is a kind of fictive use of KT; according to Braun $(1988$, p. 9) "when a KT is used for addressing someone who is not related to the speaker in one way or another, this is called a fictive use of KT".

The fictive use of a $\mathrm{KT}$ also refers to a situation in which a relative is addressed by a term different from the biological one. The fictive use of a KT is frequently seen in SK, which will be discussed in the following sections. A young person, especially in villages and small towns prefers to address an older person by a kin term, rather than using their name. In this respect, KTs are a kind of complementation to personal names. In such cases, ' $x \bar{a} t c e$ ' is used to address males and 'pure' to address females. These terms show respect for non-kins who are in a generation above the speakers.

\section{A conversation in a family:}

Father to his elder son:

\section{“kāk raesu $t \int u y$ bō mātē kāk brāyim?"}

"(my) older brother Rasoul, did you go to home of (my) elder brother Ebrahim?"

The son to his father: "baete bäbae"

$$
\text { "yes, (my) father" }
$$

According to my informants and based on some films from the past, ' $k \bar{a} k{ }^{\prime}$ ' or ' $k \bar{a} k$ ' $+\mathrm{FN}$ was used by rural speakers to address urban ones and by speakers of the low social class to address the high social class addressees. The criteria for determining low or high social classes were the amount of education, occupation and place of residence. Those with a high level of education and an occupation with high salary and having a house in the center of city are considered high class and vice versa. Gradually high class speakers reciprocated this term not to express superiority, but rather as an imitation of what low class speakers did. This is a kind of address inversion defined as "the use of a term, mostly a KT which does not (as would be usual) express the addressee, but the speaker's role in the dyad" (Braun, 1988, p. 12). The same is found in Dari, the Afghan variety of Persian, in which 'lala' ("elder brother") was used by speakers of lower social status to address the male speakers of high social status, and then, by imitation, this term was used by higher social class speakers to address lower ones (Braun, 1988: 33).

Today, 'kākce', which is a term of equality between males in both informal and semi-formal situations, is used in various contexts; this use is governed by solidarity, so it is reciprocal. 
People who are close or have a certain level of intimacy use ' $k \bar{a} k c e$ ' when addressing each other; even male strangers of about the same age use ' $k \bar{a} k c e$ ' to refer to each other when they meet for the first time. As we saw in the previous conversation, a father addressed his son as ' $k \bar{a} k a c^{\prime}$; this shows high solidarity between them. Even in some regions of Kurdistan, children refer to their father as ' $k \bar{a} k c e$ '; this also signifies high intimacy between them. These uses of ' $k \bar{a} k c e$ ' are examples of address inversion. Other examples of address inversion are when parents address their son as 'bābce' ("father"), and their daughter as 'dāyce' ("mother"), or when grandparents refer to their grandchildren, based on their sex, as 'bābi bābom' ("(my) father's father") or 'dāyki dāykam' ("(my) mother's mother"). In these cases, the same term can be reciprocated to juniors. There are two main aspects of social meaning in address inversion: (1) intimacy/affectionate, (2) difference in authority (Braun, 1988). In SK, address inversion is seen within KTs in the family, thus intimate and affectionate connections are affected by inversion.

In urban areas and especially among educated people, men refer to their wife's mother as 'dāyce' ("mother") and to their wife's father as 'māmoe' ("uncle"). A woman addresses her husband's mother as 'dāyce' and her husband's father 'bābce' ("father"). Although both instances show intimacy and politeness, it seems that ' $b \bar{a} b c e$ ' indicates more closeness than mämce. Education as a social factor influences the use of specific forms of address. In rural areas and among uneducated people, both men and women address each other's parents' as

'7āmōzən' and 'māmce'. Within the nuclear family, KTs like 'piyāwaeke' (“(my) husband”)

and 'Päfraet' ("(my) wife") are seldom used unless the family is being discussed with another family; instead of these KTs, personal names and other variants of address terms are usually used. In another pattern, especially among traditional people, husband and wife use a teknonymous mode of address: they address each other by the name of one of their children or as 'dāyki məndātān' ("children's mother") for wife and 'bābi mandātān' ("children's

father") for husband. The KTs 'bra' ("brother") and 'xōfk' ("sister”) like 'bcerādcer' and 'xāhcer' in Persian have a symbolic meaning and are used widely among those who have Islamic beliefs. They are also used between nationalists and those with patriotic feelings.

As we saw in the above explanations, the SK system of address is rooted in social structure and family structure and gives great importance to KTs. Within the family, terms of address systematically show the relationship between members according to their generation, age, sex, patrilineal kin, matrilineal kin, affinal kin and so on. Regardless of who uses these KTs and to whom they are used, they show a sense of solidarity among speakers. In these patterns solidarity does not necessarily imply equality. These KTs are neutral with regard to power in the sense that they don't show the superiority of one person over another. Non-reciprocal relationships in SK KTs involve differences in age and sex and it indicates a powerful age-sex interaction rather than status.

The use of KTs is related to the holistic tendency in Kurdish culture, where the parts need to fit into the whole network. Social ethics have a significant impact on the formation of KTs in 
Sk. SK has several thousand years of feudal history. The family in Kurdish has traditionally been the center of all the activities and is the focus of Kurdish life. Generation and age are regarded as important elements when addressing others in the same family. Blood relationship also affects the shaping of KTs which makes the KTs in Kurdish rather complex. Influenced by the feudal ethics, Kurdish established a strict clan system based on blood relationship. In one clan, there may be tens of, hundreds of, or even thousands of members living together with quite complex relations; however, under the influence of Standard Persian it is changing into a more free culture.

In Kurdish, there are two kinds of relatives: one is blood relatives which indicate relatives with blood relations; the other, is adfinis which refers to relatives formed by marriage. The terms used to address relatives on the father's side are different from those used to address relatives on the mother's side.

\subsection{Pronouns}

According to Brown \& Gilman (1960), The T form shows intimacy between speakers and the $\mathrm{V}$ form implies difference and the speaker's politeness. The T/V distinction found in other languages is not present in SK. In our observations, we did not find any instance in spoken language in which 'Pêwce' or 'Pcewce' is used to address one person. This term is only used to address more than one person. In written texts, we encountered some instances in which Pêwce was used to address one person, but they were rare and could not be generalized to the whole address system in SK. Even in some regions, like Ranye city in Iraq and in Mahabd a city in Iran, only one form namely ' $P$ Cengo' ' is used and the T/V distinction is non-existent. That is probably why the speech of some Kurdish people is considered impolite when addressing a respectable man (e.g. a professor) with 'to' (second person singular pronoun) instead of 'Somā' (second person plural pronoun) in Persian.

Since there is no $\mathrm{V}$ form in pronouns of address in SK, the T/V distinction is shown by using titles and PNs. The functional load between pronoun and noun forms of address is not identical in this culture. The second person pronoun you in SK has a larger scope: In SK, you is an integrated part of the sentence in general, and the noun forms of address such as FN and $\mathrm{T}$ are vocative in function. 
Table 7.2. pronouns of address in SK

\begin{tabular}{|l|l|}
\hline SK pronoun of address & English equivalent \\
\hline tō, Taetō & you (singular) \\
\hline Tēwae, Taewae & you (plural) \\
\hline Taengō & you (singular and plural) \\
\hline
\end{tabular}

7.3 Titles

A conversational exchange in the street:

Mohsin : “saelām Karim Pāâā"

“Hello, Mr. Karim"

Karim : "Paemon Karimem nawak Karim $P \bar{a} \gamma \bar{a}$ "

"I'm Karim ' not Mr. Karim"

This conversation indicates that $\mathrm{FN}+{ }^{\prime}$ $\Upsilon \overline{\mathrm{a}} \gamma \bar{a}$ ' is marked because it reminds us the social structure in the past in which the ' $P \overline{\mathrm{a}} \gamma \bar{a}$ 's considered themselves nobler than ordinary people, but today it is not acceptable to address people with $\mathrm{FN}+{ }^{\prime}$ 文 $\gamma \bar{a}$ '. In the above example, Mohsin irritated Karim by addressing him with $\mathrm{FN}+{ }^{\prime} ? \overline{\mathrm{a}} \gamma \overline{\mathrm{a}}$ ' and Karim mentioned his FN to be addressed with. As we indicated in 7.2, in SK the T/V distinction is shown by titles and names. These are shown in table 7.3.

Table 7.3. titles in SK

\begin{tabular}{|l|l|}
\hline titles in SK & English Equivalent \\
\hline ǰænāb, ǰænābtān & Excellency \\
\hline bærēz, rēzdār & respectable \\
\hline Tāyā & Mr. \\
\hline xānəm, xāt & Mrs. \\
\hline kwēā & Headman \\
\hline kwēxāzən & Female khan \\
\hline xān & Khan \\
\hline
\end{tabular}

These titles are called honorific titles because they show the respect of the addressor for the 
addressee. Mutual use of 'joenābtān' marks equality between speakers and emphasizes politeness or unfamiliarity in a dyad. For $\mathrm{T} / \mathrm{V}$ distinction in this regard, non-reciprocal exchange of the pronoun ' Taetō' and the title 'joenābtān' is used. In this situation, a person of HC status addresses a person of LC status with 'Toetō' and receives ' joenābtān' in return. 'bce rēz' and 'rēzdārr' are often used with FNs. They are mostly used in indirect speech, especially when referring to political and scientific figures in TV interviews. They are also used in written forms.

\section{A mother to her daughter who had broken the glass:}

\section{“xānəm Leila liwāncekat f̧kānd?”}

"Mrs. Leila, you broke the glass?"

Comparing the male and female variants of Mr./Mrs. forms, both ' Tây $y$ ' and ' $x \bar{a} n \partial m$ ' can be used with FN and LN: FN+'xānəm', 'xānəm'+FN, and 'xānəm'+LN. In these patterns, as we saw in the above example, ' $x \bar{a} n \partial m$ ' $+\mathrm{FN}$ is used to show the anger of the speaker. ' $x \bar{a} t$ ' is another variant of ' $x \bar{a} n \partial m$ '. It is used with $\mathrm{FN}$ as ' $x \bar{a} t$ ' $+\mathrm{FN}$. The variants of these for males

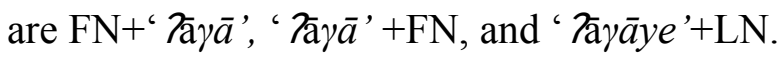

It seems that for females, language is a means of showing respect and politeness, especially in speaking to men, so women tend to address men with '?āâaye'+LN in its perfect form but men often use it in abbreviated form as 'Tây' $+\mathrm{LN}$. One of our female students told me that ' Tâyāye'+LN indicates more politeness and respect than ' Tây'+LN and it is a preferred form to address men. Pronouns and titles belong to bound forms of address, which along with nouns, they show the $\mathrm{T} / \mathrm{V}$ distinction in SK. Now we turn to nouns that are free forms of address.

\subsection{Names}

A dyad in Post Office.

The Post manager: "Mahdi nāmakēn

"Mahdi, did you bring the letters?"

\section{Ahmad: " "baele Tā Yāy Mahoemaedi?"}


"yes, Mr. Mohamadi”

The non-reciprocal use of FN and TLN marks inequality between the two speakers. The manager is addressing the clerk by FN. Hence, he considers his position being superior to the others. The clerk agrees with this consideration and addresses the manager by TLN. Thus, the relationship concerning the occupational level is a trigger for the choice of address terms.

The naming practices vary from culture to culture. A name can give us important information about the identity of an individual such as to which culture or religion they belong. In SK, names can be classified as FN, LN, and appellations. Sometimes the titles ' $7 \bar{a} \gamma \bar{a}$ ' and ' $x \bar{a} n \partial m$ ' are used with names. The LN alone is rarely used except in cases in which teachers address their students in the classrooms, because it is a mark of formality and inequality of status.

Most of the time teachers are addressed with ' $7 \bar{a} \gamma \bar{a}$ ' and ' $x \bar{a} n \partial m$ ' depending on their sex.

With regard to these explanations, there are the following possible patterns of using names:

1) Mutual use of appellations: Appellations are titles which some people give themselves and they are the result of the attributes, ideas, and prowess of a person who is appointed by others. The use of appellations is the most intimate form between members of the same age or group, and between close friends.

2) Mutual exchange of FN: In Kurdish society, a child is given a name some days after their birth. It is often a Muslim name from Quran, Islam figures, or a Kurdish or Persian name from the names of mountains, rivers and plains of the Kurdistan region or Iran. Some people have two names, one of them is the name of the identification card and the other is the name by which the person is called in the family, by friends and peers (nickname) which is marked "familiar". Sometimes People use double names to address their child; especially people with religious beliefs often choose Moslem names for their children such as Muhammad Reza, Ali Reza etc. Those for whom nationality is more important choose a Kurdish or an Iranian name like Nishtiman, Hiwa, etc. Concerning this matter, Fasold (1990, p. 29) states that: "Reciprocal T pronoun and reciprocal FN address is surely a universal result of relatively high solidarity or intimacy". People in Kurdish society become familiar to each other very easily. The reciprocal use of appellations and $\mathrm{FN}$ is analogous to the T form of pronouns. We observed instances in which after a short conversation TLN was replaced by FN. When the level of intimacy and solidarity is strong, people have, in addition to FN, other options like using KTs such as ' $k a \bar{k} k$ ', because both FN, and KT terms are signs of closeness and familiarity.

3) Reciprocal exchange of TLN: In Iran LN is the family name that paternal members of a family have in common. Mutual TLN marks equality and in most cases unfamiliarity in a conversational exchange. It is analogous to the $\mathrm{V}$ form of pronouns or $\mathrm{V}$ form of titles. It means that the child keeps their father's LN no matter if they marry or not; women do not change their LN by a marriage. In Iraq LN is one's father and grandfather's name. It is analogous to the $\mathrm{V}$ form of pronouns or titles. 
4) Asymmetrical use of FN/ TLN: It is the pattern in which one person addresses the other with FN and receives TLN. In this pattern, social differences play a considerable role in non-reciprocal exchange, because one speaker sees himself on a social level that is above the other speaker's and therefore addresses him with FN and gets back TLN in return. As we stated in the beginning of this part, occupational and social status are two determining factors for choosing a kind of address term (FN or TLN).

Although in such situations the pronoun ' Tatoto' and the title 'joenābtān' are often used to mark inequality of power, in some situations non-reciprocal FN/TLN is used for the same purpose. In addition to the above patterns, there are some other options to use. Using a title like ' Tây $y$ ', 'xānəm', 'duktōr' or a combination of titles like ' Tāyāye duktōr' is possible. They are used in most formal situations. Two strangers in the street may call each other ' $7 \bar{a} \gamma \bar{a}$ ' or ' $x \bar{a} n \partial m$ ' based on their sex or may address each other with a kinship term like ' $k \bar{a} k c e$ ' and ' $b \bar{a} j \bar{i}$ '.

The use of multiple names is very common in the Kurdish society. It is seen between intimate friends and close relatives. According to (Fasold, 1990) the exclusive use of FN is not enough as a form of address between close friends. When people become intimate, they use a variety of forms to address each other. Sometimes they use TLN, sometimes FN or nicknames, sometimes LN alone or even they create phonetic variants of FN or nicknames. In Kurdish, this depends on the situation in which the exchange takes place. In very formal situations, intimate friends may call each other with TLN, in semi-formal settings they address one another by ' $k \bar{a} k$ ' $+\mathrm{FN}$, while in informal situations the use of $\mathrm{FN}$ or nicknames is common.

\section{Two intimate friends in the street:}

- "yātlä haetiw"

- "Hi, hatiw"

- "hä xwēri"

- "Oh, khweri"

'hoetiw' and 'xweri' don't have a particular meaning. They are only phonetic variants that close friends and peers use while addressing each other. They are like appellations with the difference that appellations have a specific meaning. Both appellations and these variants are intimate forms of address.

\subsection{Religious Terms of Address}

The ideological assumptions and power relations are best highlighted in religious and political terms. 
Table 7.5. Religious terms of address in SK

\begin{tabular}{|l|l|}
\hline Religious terms in SK & English Equivalent \\
\hline Sēx & chieftain \\
\hline Jēxzən & female chieftain \\
\hline sæyēd & Sayyed \\
\hline sæyzadē & female sayyed \\
\hline sōfi & Mystic \\
\hline sōfizən & female mystic \\
\hline mælā & clergyman \\
\hline mælāzən & clergyman's wife \\
\hline māmostā & Clergyman \\
\hline dærwē & - \\
\hline xælifæ & caliph \\
\hline hāj̄i & pilgrim \\
\hline hāǰizən & - \\
\hline
\end{tabular}

All of these terms can be used with FN or alone. There are female counterparts for some of them, namely both men and women can be addressed with a specific kind of address term according to their status in religion. As we see in the table, there are not suitable equivalents for some of these terms in English and even in some other languages, which shows the status of religion in the Kurdish society. Although with the change of social structure, the meaning and use of some terms changed through time, all of them are used to some extent. Now we discuss them in turn.

\section{A conversation in a mosque:}

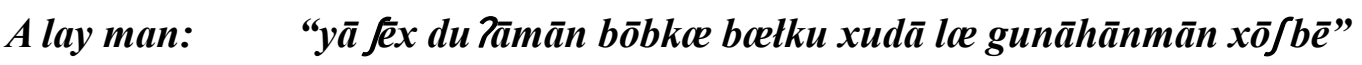

“oh, Jēx, pray for us, haply God forgive our sins"

fex: "xudā lae gunāhi hamu lāyaki $x \bar{o} \int b \bar{e} "$ 
"God forgive the sins of all (people)"

As it is evident from this conversation, people consider the ' $\int e x$ ' as an intermediator between them and God, because they have great understanding of religious commands and rituals. No matter the level of formality and age of interlocutors, the 'fex' are addressed as such in all situations even in the family. In SK, the title of ' $\mathscr{e x}$ ' is partly inherited, that is, when a man is ' $e \overline{e x}$ ', his grandson is called ' $\breve{e x}$ ' after him and he is expected to follow his father's religion. If a person addresses a ' $/ e x$ ' by his FN, he is considered impolite. This indicates the high respect for religious figures among Kurdish people. The wife of ' $\bar{e} x$ ' is addressed 'fēxzən'. The case of ' $\sqrt{e x}$ ' is different in some Arabic countries. According to Braun (1988) in Egyptian Arabic, ' $\mathfrak{e x}$ ' is used by non-' $/ e x s '$ for addressing friends, neighbors, relatives, etc as a sign of annoyance. In this pattern it resembles a fictive use of KTs and might be interpreted as an imitation of a superior's inversion behavior in authority addressing inferiors. The 'fexs' appoint some people as their representatives to go to villages and small towns to preach their religion. These are called 'xcetifce'. 'xcetifce' is addressed to both men and women.

The household of the prophet Muhammad are addressed 'sceyèd'. This term seems to be common among all Muslims. The wife or daughter of a 'sceyèd' is 'scyzade'. Those who are 'sceyed' are addressed so almost in all contexts. Among lay people, it is believed that the 'sceyed' have relationship with God and prophet and they are called, esp. in confronting problems and formidable situations. People are very careful in addressing 'sceyed' lest to annoy them because they are of great honor among the Muslim SK people. The other religious term is ' $s \bar{o} f i$ '. Although its use in recent years is greatly abolished, it is still common in some parts of Kurdistan. The mark of the 'sōfi' is that they have long beards and moustaches and they spend most of their time in mosques, reading the Quran and praying. It is believed that they have spiritual powers and become united with God to reach truths that is impossible for lay people to understand.

\section{Two friends at school:}

- “maelā Karim daersakānot xwendun?"

- "Clergyman Abdullah, did you study your lessons?

- “hēndēk"

- "A little" 
The case of 'mcela' ' is different from other religious terms. Its actual use is to address those who preach Islam and serve as religious Imams on Fridays. It also has other uses. As we saw in the above example, it is used by non-'mcelās' for addressing friends, neighbors, relatives, etc. as a joke and in some cases as a sign of annoyance. This resembles ' $/ e x$ ' in Egyptian Arabic. Another use of 'mcelà' is when the 'mcelā' addresses other people with 'moela'. In this pattern, it is an interchangeable term and it is like address inversion of KTs.

'Māmostā' is a term for religious leaders, esp. in religious parties and by those within the same party. 'Māmostā' has a historical perspective with itself. Before the Islamic Revolution teachers were addressed 'mämostā'. That is because they served both as teachers and religious leaders in those regions. Even now in some remote areas in Iran, and also in most parts of Iraq, 'māmostā' is used to address teachers. Within religious parties, men and women address each other $b r \bar{a}$ and ' $x u f k$ '.

In SK, ' $h \bar{a} \breve{l}$ ' serves as a mode of address. As a general rule, ' $h \bar{a} \tilde{J}$ ' i is used to address a person who has undertaken the pilgrimage to Mecca. Whatever the position or status of a person would be, when they perform the ' $h a j$ ' ceremony, ' $h \bar{a} / \tilde{i}$ ' is employed to address them in most situations. In Arabic and in a couple of other languages, ' $h \bar{a} \tilde{j} i$ ' is used among acquaintances to those who performed the ' $h a \jmath$ ' ceremony and among strangers it can be employed as an address term in general. In Iran, after the Islamic Revolution, 'hä̌li' was used as a term of respect for old people and this influenced the Kurdish society and now ' $h \bar{a} / \bar{l}$ ' is a common term to refer to old Kurdish speakers. Nowadays, this term has negative connotation among people and esp. youth.

Another religious term is 'dcerwē $\int$. Lay people think that the 'dcerwē $\int$ have magical powers and do extraordinary things like eating glass, cutting their head, etc. In recent years this belief is mainly abolished and so the use of 'derwēe $\int$ has decreased to a great extent. Those who believe in the extraordinary power of the 'doerwē $\int$, still use this term to address them.

From the above explanations it is clear that the SK is closed and rigid in respect of religious terms because every person has a specific role in religion and is addressed based on this role. Interestingly enough, religious terms are unaffected by level of formality, age of speakers, class, education, etc. What is important is the belief of speakers in a dyad.

The use of these terms indicates that religious figures are in great honor in the Kurdish 
society and although some changes may occur from time to time regarding the use of these terms, they are not of considerable importance. All these show the status of religion in the Kurdish society.

All of these terms can be used with FN or alone. There are female counterparts for some of them, namely both men and women can be addressed with a specific kind of address term according to their status in religion. As we see in the table, there are not suitable equivalents for some of these terms in English and even in some other Iranian languages, which shows the status of religion in the Kurdish society. Although the meaning and use of some of these titles changed through time in the course of the change of the social structure, all of them are still used to some extent today. Now we discuss them in turn.

\subsection{Political Terms of Address}

As was stated before, power is exerted in two ways: through coercion, that is over language. The sources of power are various and the most important kind is political power. Ideological assumptions play a significant role in addressing political figures. The struggles and disputes that occur in language are based on power relations between people. Power is exerted in two ways: through coercion, that is over language and through manufacturing of consent, which is with language. The sources of power are various and the most important kind is political power. Ideological assumptions play a significant role in addressing political figures. There are not political parties in the Kurdistan of Iran, so we had to refer to the TV and radio programs in Iraq for data collection with regard to political terms of address. There are only a limited number of political terms in SK as follows:

Table 7.6. political terms of address in SK

\begin{tabular}{|l|l|}
\hline political terms in SK & English Equivalent \\
\hline særōk & leader - president \\
\hline rēbær & Leader \\
\hline hævāł & comrade \\
\hline hāwrēe & Comrade \\
\hline xātu & - \\
\hline
\end{tabular}

Since there is rarely a face-to-face interaction between political figures and the lay people, in most situations these terms refer to others, not to the addressee. we only found in TV and radio interviews and conferences that these terms refer to the addressee. For the clarification of political terms, we refer to some extracts form TV programs.

\section{In a news conference:}


"Excellency leader, what's your opinion about karkuk"

\section{Mas 7oud Barzani, “tō daezāni karkuk maesaelayaki zōr gringae”}

"You know karkuk is a very important matter"

In this conference, the correspondent doesn't suffice with 'scerōk' and supplements it with ‘joenā $b$ ' to address Mas?oud Barzani, the leader of Iraqi Kurdistan. It shows the high respect and politeness towards political leaders. The correspondent receives to (you, singular) in return. This exchange indicates how power influences the selection of a specific variant of address term.

\section{In the news:}

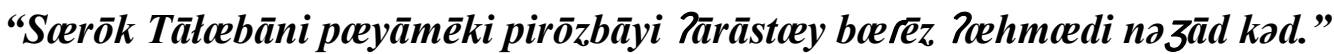

"Leader talebani sent a congratulatory message to respectable Ahmadi Nejad."

\section{In the news:}

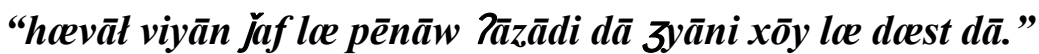

"Comrade Vian Jaf passed away for the sake of freedom."

hoeva $\bar{a} t$ has connotations of respect, intimacy and solidarity and is used between equal powers in politics. Sometimes titles 'bcerēz' or ' figures as we saw in example 2. 'Xātu' is a respect term for women who serve as political leaders. It underwent the process of narrowing because in the past it was used as a respect form for all women.

We understand from these explanations that the Kurdish language is static with regard to political terms because the political structure is like a pyramid in which everyone has a special position and is thus addressed according to this rank. These terms mostly refer to others, and so they are not concerned with social factors like age, sex, class, level of formality of situation, etc. The significant role is based on the conventions that people make to address political figures. In addition, as we saw earlier, some of the political terms do not exist in post-revolutionary Iran anymore. The reason is the entire social change after the Islamic Revolution, of course at the beginning of revolution and the prevalence of solidarity semantics over power semantics.

\subsection{Occupational Terms of Address}

Occupational terms are also used to address people in Kurdish. We can recognize the following occupational terms. 
Table 7.7. occupational terms of address in SK

\begin{tabular}{|l|l|}
\hline occupational terms in SK & English Equivalent \\
\hline wæstā & artisan \\
\hline rāwtfi & Hunter \\
\hline Sōfir, rānændæ, sāyēq & driver \\
\hline Tāmuzgār & teacher \\
\hline duktōr & doctor \\
\hline qāzi & Judge \\
\hline Tōstād & university professor \\
\hline muhændis & engineer \\
\hline sistær & nurse \\
\hline
\end{tabular}

These terms can be categorized into two types: traditional and modern. The first three from the above table are traditional and the rest are modern. 'rāwtfii' is used alone. 'fofir' is used with ' $k \bar{a} k$ ' and 'wcesta ' can be used alone or with FN to address their practitioners. 'wcesta' ' is used to address the practitioners of many jobs, to a skillful and experienced craftsman, to tailors, blacksmiths, painters, carpenters, bakers, repairmen, etc. 'Rāwtfi' and 'fófir' are only used when their practitioners are doing their jobs. For example, when a person is hunting, he is called ' $r \bar{a} w t f i$ '. In other situations, he is addressed with other variants like FN, title and LN,

$\mathrm{KT}$ and so on based on the situation. The variant for ' $f \bar{f} f i r$ ' in Iraq is 'sāyequ'. After the Islamic Revolution, due to much interaction with Persian speakers, the term 'rānoendoe' entered into SK. With the appearance of new jobs, these terms were no more sufficient to address the practitioners of jobs and so SK borrowed some terms from other languages. The main reason for this borrowing was the sense of need, because there were not appropriate terms for these jobs in SK.

Nowadays ' $7 \bar{a} m u z g \bar{a} r$ ' is only used in remote villages. This term came into SK because in the past, most of the teachers in Kurdistan were Persian speakers and students addressed them as ' Tāmuzgārr' and villagers kept this term for today. In cities and towns teachers are simply addressed with title and LN. Other modern occupational terms are used to a great extent in 
SK. The case of 'sistcer' will be discussed in next section.

\subsection{Endearment Terms in SK}

Parents, particularly mothers invent specific forms to address their small children. The literal meaning of these terms has nothing to do with address forms; they are only used to address children. These terms are also found between other members of the family and close friends.

Table 7.8. terms of endearment in SK

\begin{tabular}{|l|l|}
\hline Terms of Endearment & English Equivalent \\
\hline tfāwækæm & my eye \\
\hline ǰrgækæm & my liver \\
\hline dəłækæm & my heart \\
\hline giyānækæm & my dear \\
\hline ruhækæm & my soul \\
\hline ?æmrækæm & my life \\
\hline ?æzizækæm & my dear \\
\hline
\end{tabular}

Most of these terms are parts of body that serve as address forms. It is because mothers consider their children as parts of their body. This shows the great affection of mothers for their children. What was stated in this section is a general picture of the address system in SK, but it is not exhaustive in any way. People sometimes may resort to no name strategy, that is, when speakers are not sure of the social relationships in a specific situation, they avoid using any kind of address terms. Furthermore, power and solidarity are relative concepts and may be different from a community to another and even between individuals in the same community. In addition, politeness is not definitely defined. What is considered polite in a specific time and place may by rude in another environment. A close understanding of address system needs taking into account all these factors, a very hard if not an impossible task.

\section{Innovations in SK Address System}

Several innovations happen in the Kurdish address system, most of which have been made after the 1979 Islamic Revolution.

\subsection{Semantic Changes of Address Terms in SK}

Traditional Kurdish society had a social structure that was predominantly hierarchical, feudal and elitist. In this structure, the non-reciprocal power governed the address behavior and power was distributed by birthright. ' $7 \bar{a} \gamma \bar{a}$ ' or "FN $+7 \bar{a} \gamma \bar{a}$ " was used to address those 
noblemen who had a lot of land and employed others to work on their land. They were also the government's representatives in towns and cities. In other words, ' $7 \bar{a} \gamma \bar{a}$ ' had connotations of class, wealth and status. In the Kurdistan province, they were addressed ' $b c e g$ ' and in cities like Mahabad, Boukan, etc, people used ' $x \bar{a} n$ ' to refer to their landlord. The headman of a village was ' $k w \bar{e} x \bar{a}$ '. The ' $k w \bar{e} x \bar{a}$ ' were intermediators between the ' $7 \bar{a} \gamma \bar{a}$ ' and the lay people.

The power of ' $k w \bar{e} x \bar{a}$ ' was less than that of an ' $\bar{a} \bar{\gamma} \bar{a}$ ' and they were also in lower class standing. The people who worked on the ' $7 \bar{a} \gamma \bar{a}$ 's lands and home referred to themselves as 'nōkcer' ("slave"). Because in such a society status was fixed, every person had enduring rights and obligations of address and there was little mobility in the address system.

Before the Islamic Revolution, there were a few educated people in Kurdistan and education was restricted to people of higher social class and the noble. Address forms like ' mirz $\bar{a}$ ' and ' $m \bar{a}$ moest $\bar{a}$ ' were linguistic badges of elitism. With the Islamic Revolution, the Kurdish society like other societies in Iran changed rapidly. These changes were sensible in every aspect of life, even in using language. The Islamic Revolution had the idea that all people are equal and there is no superiority of one person over another and in the cornerstone of this belief solidarity semantics developed. Solidarity is reciprocal and has grown with social mobility and equalitarian ideology. It is believed that the approval of agrarian reform changed the Iranian social structure, but it did not affect the Kurdish society. When the Islamic

Revolution reached victory and class distinctions were abolished, FN+' $7 \bar{a} \gamma \bar{a}$ ' was replaced

with ' $7 \bar{a} \gamma \bar{a} y e$ ' $+\mathrm{LN}$ as a polite form. 'boeg' and ' $k w \bar{e} x a$ ' were eradicated. ' $X \bar{a} n$ ' is now used with FN as a title of respect for addressing men and women. 'Mirz $\bar{a}$ ' is now only used to address old people in villages and towns who have little education and can read and write.

In a dynamic society, solidarity semantics tends to govern the address behavior, while in a static society, power semantics is the prevailing rule. Regarding the Kurdish society, with the change of social structure, solidarity semantics won over power semantics and this confirms Brown \& Gilman's (1960) prediction with regard to overcoming solidarity over power.

\subsection{Borrowed Terms of Address in SK}

The SK borrowed from Persian words for such things as mother 'māmān', aunt ' Toemme', uncle 'dāyi' and so on. Since SK had native terms for these kins before contact with Persian, the motivation for these borrowings was not need, rather prestige was. Geographical factors have a strong influence on this kind of borrowing. For example, cities and towns which are close to Persian speaking areas, and their people have much interaction with native speakers of Persian, use the above-mentioned terms more than others. In the Kurdistan of Iraq, because there is no contact with Persian speakers, these terms are never used. 
Kurdish people don't have army forces of their own and they borrow terms from Persian in Iran and from Arabic in Iraq. In Iran, they use terms like 'joenāb scerwān' "excellency captain", 'scerkār' ("soldier"), ... to address army forces with based on their rank. In Iraq people often use 'sceyyed' $i$ ("my leader") to refer to army figures. People who work in cowsheds and brick-kilns use ?aerbāb to refer to their landlord. There was the word ' Paerbāb' in Kurdish but it was not used as a term of address. After the Islamic Revolution, some people in Kurdistan had to leave their hometown and go to big cities to find jobs. Those who get a job refer to their master as ' Taerbā $b$ '. In fact Kurdish borrowed ' Taerbāb' from Persian as a term of address.

SK borrowed 'mistcer' from English. Due to the influence of English over Kurdish, speakers in Iraq use 'misteer' as a polite form of address. According to Paulston (1976) in the first half of the twentieth century in Sweden doctors and dentists addressed their nurse as 'sistcer'. For reasons not known, this term came into SK and now people in Iraq use it in their speech.

\section{Discussion}

Wodak \& Meyer (2001, p. 2) define CDA as "fundamentally concerned with analyzing opaque as well as transparent structural relationships of dominance, discrimination, power and control as manifested in language". Language itself does not have power, and its power comes from unequal power relations between the members of a society. In what follows, we am going to critically investigate address terms in Kurdish. Doing a critical investigation takes us well into the political and social structures of Iran. In the past, the Kurdish society had a feudal and elitist system.

In that structure, ' $7 \bar{a} \gamma \bar{a}$ ' and ' $k w \bar{e} x \bar{a}$ ' were prominent terms of address because of their great

power. The 'rce Zyoet' "slaves" and farmers had to give a portion of their land's products to

them. When a person visited a village or town, it was the right of ' $7 \bar{a} \gamma \bar{a}$ ' or ' $k w \bar{e} x \bar{a}$ ' to treat him and the lay people did not have such a right. They also acted as intermediators between people in struggles and conflicts. When religious figures visited the town, the 'fex' or 'moela' ' came to see them. This caused these titles became well-known in the Kurdish society. These titles were also a sign of power of their owners. In this case, there was little or no mobility in power relations. This is also true for political leaders that are addressed with special terms of address and they receive much more attention among people. We think this is the case not only for Kurdistan, but among all nations and in all times, national and political leaders prevent the division of attention of people. In the case of static societies and in specific periods of time this comes closer to reality and is highlighted more clearly. For example, in the pre-revolutionary era in Iran and before the 1991 uprising in Iraq, there were some terms 
of address used only to address political and national leaders and the lay people had some specific terms to refer to themselves. What cause the use of some address terms are power relations and ideological assumptions. Power is about differences in society and the effect of these differences in organizing and sustaining social structures (Wodak \& Meyer, 2001). These differences are based on differences in position, experience and interests of speakers in a speech community which interact with each other in terms of power. As we saw in 7.4 in the exchange in Post Office, the higher occupational status of the manager leads him to address his fellow clerk with FN and receive TLN in return. It seems that occupational status plays a crucial role in asymmetrical uses of address terms not only in the SK, but also in other dialects and languages, so it contributes to sustaining unequal power relations and legitimizes the use of specific terms of address.

When we address people, especially political, religious and scientific figures, we take it for granted that some conventions embody ideological assumptions. These assumptions directly or indirectly legitimize existing power relations. In 7.6. we saw how Mas?oud Barzani, the leader of Iraqi Kurdistan, was addressed with 'joenābi scerōk' "excellency leader" by the correspondent, or in the mosque, the religious leader was addressed by ' $e x$ '. People use these titles without thinking, so ideology is an important aspect of establishing and maintaining unequal power relations (Wodak \& Meyer, 2001, p. 10).

One of the social factors that is of considerable importance to study address terms is politeness. What is considered politeness has a strong relationship with power. Fairclaugh $(1989$, p. 66) states this view as "politeness is based upon recognition of differences of power, degrees of social distance, and so forth, and oriented to reproducing them without change". The way that students address their teachers and professors is based on the politeness theory. But politeness may be different from one society to another or between members of the same society or even from one situation to another. In 7.1 it was said that how the inappropriate use of 'māmee' was regarded impolite and led to misunderstanding.

The difference between the $\mathrm{T}$ form and the $\mathrm{V}$ form in all languages, including $\mathrm{SK}$, is the difference in power relations: The $\mathrm{T}$ form to address powerless people and the $\mathrm{V}$ form to address powerful people. The development of $\mathrm{V}$ to $\mathrm{T}$, namely from power to solidarity, seems to be in line with developments across whole ranges of institutions. Much time is needed for such developments and changes to occur. With respect to the SK address system, the 1979 Islamic Revolution in Iran and the 1991 uprising in Iraq are starting points for such changes and now solidarity governs address behavior more than power.

The above explanation tells us that the aim of language is not only to transmit information and knowledge but language is also a medium of domination and social force. It serves to legitimize relations of organized power. In so far as the legitimations of power relations, ... are not articulated, ... language is also ideological" (Wodak \& Meyer, 2001, p. 2). 


\section{Summary and Conclusion}

The analysis of our corpus with many contemporary recorded conversations suggests that in every period of time, a specific instance of social structure is shown by address terms. The social groups that attribute most importance to politeness and address forms are the groups in the lower of the social scale. The lower class, with or without title, was the most affected one by this problem, which became a genuine obsession for many families. The SK system of address is rooted in social structure that gives great importance to the kinship system. The KTs in Kurdish are neutral with regard to power and non-reciprocal relationships in KTs are due to differences in age and sex rather than power.

In some languages, including Persian, the $\mathrm{T} / \mathrm{V}$ distinction is marked by using pronouns, but in SK it is shown by using titles and names. Among names, mutual exchange of first name and appellations is analogous to $\mathrm{T}$ and the reciprocal use of TLN is parallel to the $\mathrm{V}$ form. The asymmetrical use of FN/ TLN is a pattern in which a superior addresses an inferior with FN and receives TLN in return. In this pattern, occupational and social statuses play a significant role in non-reciprocal behavior. Sometimes close friends and peers make use of multiple names, that is, according to the situation of conversation they use a specific kind of address term. In some cases in which solidarity and familiarity are sufficiently strong, speakers can use kin terms apart from names, but the meaning of solidarity and the level of solidarity varies from one society to another and even between members of the same society.

In religious and political titles, ideological assumptions of people are very important, because when someone addresses a political or religious figure, it is based on implicit assumptions that arise out of and/or give rise to power relations in the society. Shortly, the powerful sectors of the society do not to change the status quo. But there is a group of unsatisfied people who push to move upwards in society. What is stated here is not exhaustive in any way because they are only samples of real instances of using address terms in SK and a complete study of address forms requires samples of both real and ideal behavior which are not always identical.

SK is very rich in expressing different shades of social meaning in the use of address terms. In every period of time, a specific instance of social structure is shown by address terms. The traditional Kurdish society had a social structure that was primarily a caste society and every person had a specific right of address from the time of their birth. In that structure, non-reciprocal power governed the address behavior and there was little or no mobility in the address system. With the advent of 1979 Islamic Revolution in Iran and the 1991 uprising in Iraq some changes in the social structure occurred, and consistent with these changes, the address system also changed considerably.

\section{List of Abbreviations}

T/V (tu/ vous), FN (first name), T (title), LN (last name), TLN (title and last name), PN (personal name), KTs (kinship terms), CDA (critical discourse analysis), SK (Sorani Kurdish), subjects $\left(\mathrm{S}_{\mathrm{s}}\right)$, lower class (LC), high class $(\mathrm{HC})$ 


\section{References}

Bates, E., \& Benigni, L. (1975). Rules for address in Italy: A sociolinguistic survey. Language in Society , 4, 271-88. http://dx.doi.org/10.1017/S0047404500006679

Braun, F. (1988). Terms of Address: Problems of Patterns and Usage in Various Languages and Cultures. Berlin: Mouton de Gruyter.

Brown, R., \& Ford, M. (1961). Address in American English. Journal of Abnormal and Social Psychology , 62, 375-85. http://dx.doi.org/10.1037/h0042862

Brown, R., \& Gilman, A. (1960). The Pronouns of Power and Solidarity. In T. A. Sebeok (Ed.), Style in Language (pp. 253-76). Cambridge: MIT press.

Brown, R., \& Gilman, A. (1972). The Pronouns of Solidarity and Power. In P. P. Giglioli (Ed.), Language and Social Context (pp. 252-82). Harmondsworth: Penguin.

Brown, R., \& Levinson, S. (1978). Universals in Language Useage: Politeness Phenomena. In Goody (Ed.), Questions and Politeness: Strategies in Social Interaction (pp. 56-311).

Bryman, A. (1984). The Debate about Quantitative and Qualitative Research: a Question of Method or Epistemology? The British Journal of Sociology , 35(1), 75-92. http://dx.doi.org/10.2307/590553

Fairclaugh, N. (1989). Language and Power. London: Longman.

Fasold, R. W. (1990). The Sociolinguistics of Language: Introduction to Sociolinguistics. Basil: Blackwell.

Foley., W. A. (1997). Anthropological Linguistics: An Introduction. Basil: Blackwell Publishers Inc.

Halliday, M. A. (1978). Language as Social Semiotics. London: Edward Arnold.

Hodge, R., \& Kress, G. (1996). Language as Ideology. London and New York: Routledge.

Lee-Wong, S. M. (1994). Address Forms in Modern China: Changing Ideologies and Shifting Semantics. Linguistics , 32, 299-324. http://dx.doi.org/10.1515/ling.1994.32.2.299

Mcgivney, J. (1993). Is She a Wife or a Mother?: Social Order, Respect and Politeness in Mijikenda. Cambridge: Cambridge University Press. http://dx.doi.org/10.1017/S0047404500016900

Oyetade, S. O. (1995). A Sociolinguistic Analysis of Address Forms in Yoruba. Language in Society , 24(4), 515-35. http://dx.doi.org/10.1017/S004740450001900X

Paulston, C. B. (1976). Pronouns of Address in Swedish: Social Class Semantics and a Changing System. Language in Society, 5, 359-86. http://dx.doi.org/10.1017/S004740450000717X

Saberi, K. (2002). A Study of Understanding Level of non- Farsi Speakers of the Social Functions. Tehran, Iran: Allame Tabatabaei University. 
Sandel, T. L. (2002). Kinship Address: Socializing Young Children in Taiwan. Western Journal of Communication , 66, 257-280. http://dx.doi.org/10.1080/10570310209374737

Van Leeuwen, T. (1993). Genre and Field in Critical Discourse Analysis: a Synopsis. Discourse \& Society , 4, 193-223. http://dx.doi.org/10.1177/0957926593004002004

Wodak, R., \& Meyer, M. (2001). Methods of Critical Discourse Analysis. London: Sage Publication Ltd. http://dx.doi.org/10.4135/9780857028020.d6

Wolcott, H. (1994). Description, Analysis and Interpretation in Qualitative Inquiry. London: Sage Publication Inc. 